\title{
Schooling of Students with Intellectual Disabilities: Family and School Perspectives
}

\author{
Ana Paula Pacheco Moraes Maturana' ${ }^{1}$ (D) https://orcid.org/0000-0002-3458-5399 \\ Enicéia Gonçalves Mendes ${ }^{2}$ (D) https://orcid.org/0000-0003-3673-0681 \\ Vera Lúcia Messias Fialho Capellini' ${ }^{1}$ (D) https://orcid.org/0000-0002-9184-8319
}

\begin{abstract}
Educational policies aimed at school inclusion have led to an increased enrollment of students with special education needs (SEN) in mainstream schools and, as a result, there is an increase in transfers from specialized institutions to mainstream schools. This study analyzed the perspectives of school professionals and family members on school transfers of students with intellectual disabilities (ID). Six family members and ten school professionals participated in the study. All attended semi-structured interviews, whose analysis allowed us to identify five thematic axes: teacher training; lack of preparation and information; lack of supports; lack of preparation for transfer; expectations regarding the ID student, mainly concerning behavioral characteristics, learning and performance. Results confirm data from research on the implementation of special education in inclusive environments, indicating that teachers', managers' and families' conceptions of inclusion depend on the severity of the student's disability, and on the skills and attitudes of the professionals.
\end{abstract}

Keywords: inclusion, special education, intellectual disability, school transference

\section{Escolarização de Alunos com Deficiência Intelectual: Perspectivas da Família e Escola}

\begin{abstract}
Resumo: Políticas educacionais voltadas à inclusão escolar têm levado ao aumento de matrículas de alunos público alvo da educação especial (PAEE) na escola comum e como resultado observa-se aumento de transferências das instituições especializadas para escolas comuns. O estudo analisou as perspectivas de profissionais da escola e familiares sobre as transferências escolares de alunos com deficiência intelectual (DI). Participaram seis familiares e dez profissionais da escola. Todos responderam a uma entrevista semiestruturada, cuja análise permitiu identificar cinco eixos temáticos: formação do professor, despreparo e falta de informação; falta de suportes; ausência de preparo para a transferência; expectativas quanto ao aluno com DI em relação às características comportamentais, aprendizagem e desempenho. Os resultados ratificam dados presentes em pesquisas sobre a implementação da educação especial em ambientes inclusivos, sinalizando que concepções dos professores, gestores e familiares frente à inclusão dependem da severidade da deficiência do aluno, das habilidades e atitudes dos profissionais.
\end{abstract}

Palavras-chave: inclusão escolar, educação especial, deficiência intelectual, transferência escolar

\section{La Escolarización de Alumnos con Discapacidad Intelectual: Perspectivas de la Familia y de la Escuela}

\begin{abstract}
Resumen: Las políticas educativas hacia la inclusión escolar están aumentando las matrículas de alumnos, público objetivo de la educación especial, en la escuela común, y como consecuencia se observa un incremento de transferencias de las instituciones especializadas para las escuelas comunes. El estudio analizó las perspectivas de profesionales de la escuela y de familiares sobre las transferencias escolares de alumnos con discapacidad intelectual (DI). En él participaron seis familiares y diez profesionales de la escuela. Todos los participantes respondieron a una entrevista semiestructurada, cuyo análisis permitió identificar cinco ejes temáticos: la formación del profesor, falta de preparación y de información; la ausencia de soportes; la ausencia de preparación para la transferencia; las expectativas en cuanto al alumno con DI en relación a las características conductuales, de aprendizaje y de desempeño. Los resultados confirman datos presentes en investigaciones sobre la implementación de la educación especial en ámbitos inclusivos, señalando que las concepciones de los profesores, gestores y familiares frente a la inclusión dependen de la severidad de la discapacidad del alumno, de las habilidades y actitudes de los profesionales.
\end{abstract}

Palabras clave: inclusión, educación especial, discapacidad intelectual, transferencia de escuela

\footnotetext{
${ }^{1}$ Universidade Estadual Paulista, Bauru-SP, Brazil

${ }^{2}$ Universidade Federal de São Carlos, São Carlos-SP, Brazil

Article derived from the doctoral dissertation of the first author, under supervision of the second author, defended in 2016 in the Graduate Program in Special Education of the Federal University of São Carlos.

Correspondence address: Ana Paula Pacheco Moraes Maturana. Universidade Estadual Paulista. Faculdade de Ciências, campus Bauru. Avenida Engenheiro Luiz Edmundo Carrijo Coube, $n^{\circ}$ 14-01, Vargem Limpa, Bauru-SP, Brazil. CEP 17.033-360. Email: ana.maturana@unesp.br
}

The school environment has been permeated by several discussions on the inclusion of students with special education needs (SEN). Such discussions aim to enlighten the school community with reflections and proposals of practices on the "how-to" of inclusion. In the specific case of students with intellectual disabilities (ID), who represent the largest contingent within 
special education (SPED) students, the tradition prior to the school inclusion policy was that of schooling in a specialized institution and/or special schools; today, they share the stage with this new proposal of schooling in mainstream schools. It is evident the educational policy has increasingly tried to make compulsory the enrollment of all SPED students in the mainstream school, although in the case of students with ID this measure has run counter to the Brazilian historical tradition of placement in specialized institutions and special schools (Veltrone \& Mendes, 2012). The result of this has been the increased flow of school transfers of students from special to mainstream schools, as well as the return of these pupils back from mainstream school to special school.

However, school transfers that occur in an attempt to adapt to the current inclusion policy are not always successful or result in benefits for the student's schooling. This is because there is a movement that must precede the enrollment of the disabled student in the mainstream school. The movement of opening the school to differences, be they of learning, gender, culture, socioeconomic and all other forms of diversity, guarantees to the human being the right to its singularity. Such movement must be based on the subjectivity of school professionals, family members and society in general, to then become a practice, i.e., the need for inclusion and respect for the different ways of learning must be understood and accepted in a trustworthy manner and above all "as a moral imperative of presentday society" (Omote, 2003, p. 154).

Omote, Oliveira, Baleotti and Martins (2005) recall that most teachers did not receive specialized training or support to deal with the situation. However, to promote inclusive education, it is not enough to provide professional training for the use of techniques and resources. One needs to build "a new vision of teaching and learning, based on attitudes genuinely favorable to inclusion" (Omote et al., 2005, p. 388). Therefore, school inclusion should transcend the mere student enrollment and placement in the common room, the "letting in", so as not to run the risk of exclusion in inclusion. For Oliveira, Valentim and Silva (2013), real inclusive spaces involve the transformation of the school into a democratic, plural environment, open to differences and able to combat any exclusion process. School inclusion involves collective, political and ethical commitment.

Considering the challenges inherent to this paradigmatic transformation of the school reality, some research aims to bring light and important reflections on the schooling of students with ID. Some studies that analyzed the school trajectory of students with ID in mainstream schools show that, in most cases, pedagogical practices and academic activities of regular classrooms have not undergone any transformation or adaptation to attend to the specific educational needs of these students, nor even to consider the heterogeneity of the class (Carneiro, 2008; Duarte, 2012; Pletsch \& Glat, 2012). Pletsch and Glat (2012) pointed out the resistance by managers and teachers to the inclusion of students with ID in general education classrooms, even more than to other conditions such as physical and sensory impairments. For the authors, "one must consider the overvaluation of cognitive abilities present in the educator' conceptions, which makes these subjects, in their perceptions, ineligible for formal learning" (Pletsch \& Glat, 2012, p. 198).

Regarding education professionals and family members, there is a divergence of conceptions and feelings regarding the process of school inclusion. Lima and Mendes (2011) applied an interview on 24 relatives of students with ID. As for the perceptions of family members, 14 were positive, considering that the child really learned the scholarly knowledge. However, seven participants pointed out their children did not learn and six reported they sometimes believed their children learned, sometimes not. In all reports of negative perceptions, both by education professionals and by family members, one can see the fault for not learning is attributed to the student - usually seen as slow -, showing the lack broader view of learning as a multi-determinate process (Lima \& Mendes, 2011).

In this sense, this study aims to investigate these students' transfer processes from specialized institutions to mainstream schools and vice versa, from the perspective of their school professionals and family members. To this end, the general objective of the study was to analyze the perspectives of school professionals and family members on the school transfers of students with ID.

\section{Method}

This is a descriptive, qualitative research that has adopted the multiple case study design as proposed by Yin (2014). The choice for this design allowed "the investigation of a contemporary phenomenon within its real-life context, especially when the boundaries between phenomenon and context are not clearly defined" (Yin, 2014, p. 32).

\section{Participants}

Sixteen people participated in the study, six of whom were family members and/or guardians and ten were professionals from the school. All were directly or indirectly involved in the transfer process of students with ID from special to mainstream school and vice versa. Table 1 shows the participants' characteristics and their relationships with the five students with ID (identified with the letter E). 
Maturana, A. P. P. M., Mendes, E. G., \& Capellini, V. L. M. F. (2019). Schooling of Students with Intellectual Disability.

Table 1

Characterization of research participants

\begin{tabular}{|c|c|c|c|c|c|c|}
\hline \multicolumn{7}{|c|}{ Family members } \\
\hline Initials & Age & Kinship & Occupation & Education level & Student & Current school \\
\hline $\mathrm{F} 1$ & 42 years old & Mother & Beautician & Incomplete elementary school & E1 & Mainstream \\
\hline $\mathrm{F} 2$ & 71 years old & Grandmother & Retired & Incomplete elementary school & E2 & Special \\
\hline $\mathrm{F} 2 *$ & 75 years old & Grandfather & Retired & Incomplete elementary school & E2 & Special \\
\hline F3 & 24 years old & Sister & Craftswoman & Completed High School & E3 & Special \\
\hline F4 & 25 years old & Mother & Beautician & Completed Elementary School & E4 & Mainstream \\
\hline F5 & 34 years old & Mother & Cleaner & Incomplete elementary school & E5 & Mainstream \\
\hline \multicolumn{7}{|c|}{ Education Professionals } \\
\hline Initials & Age & Graduation & Occupation & $\begin{array}{c}\text { Graduate in } \\
\text { Special Education }\end{array}$ & Student(s) & Workplace \\
\hline PE1 & 37 years old & $\begin{array}{l}\text { Teachers } \\
\text { Training; } \\
\text { Pedagogy }\end{array}$ & $\begin{array}{l}\text { Elem. school } \\
\text { teacher }\end{array}$ & Yes & E1;E3 & Special School \\
\hline PE2 & 53 years old & $\begin{array}{l}\text { Teachers } \\
\text { Training; } \\
\text { Pedagogy }\end{array}$ & $\begin{array}{l}\text { Elem. school } \\
\text { teacher }\end{array}$ & Yes & $\mathrm{E} 2 ; \mathrm{E} 5$ & Special School \\
\hline PCE1 & 41 years old & Teaching & $\begin{array}{l}\text { Elem. school } \\
\text { teacher }\end{array}$ & Yes & $\mathrm{E} 1 ; \mathrm{E} 4$ & $\begin{array}{c}\text { Special and } \\
\text { Mainstream School }\end{array}$ \\
\hline PC4 & 29 years old & Pedagogy & $\begin{array}{l}\text { Elem. school } \\
\text { teacher }\end{array}$ & No & E4 & Mainstream School \\
\hline PC5 & 27 years old & $\begin{array}{l}\text { Pedagogy; } \\
\text { Language \& } \\
\text { Literature }\end{array}$ & $\begin{array}{l}\text { Elem. school } \\
\text { teacher }\end{array}$ & No & E5 & Mainstream School \\
\hline PSRM & 34 years old & $\begin{array}{l}\text { Teacher } \\
\text { Training; } \\
\text { Pedagogy }\end{array}$ & Prof. SRM & Yes & $\mathrm{E} 1 ; \mathrm{E} 2$ & Mainstream School \\
\hline $\mathrm{CP} 1$ & 36 years old & $\begin{array}{l}\text { Teachers } \\
\text { Training; } \\
\text { Pedagogy }\end{array}$ & $\begin{array}{l}\text { Educational } \\
\text { coordinator }\end{array}$ & Yes & $\mathrm{E} 1 ; \mathrm{E} 2$ & Mainstream School \\
\hline DE & 32 years old & Pedagogy & $\begin{array}{l}\text { School } \\
\text { principal }\end{array}$ & Yes & All & Special School \\
\hline DC1 & 57 years old & $\begin{array}{l}\text { Teachers } \\
\text { Training; } \\
\text { Pedagogy }\end{array}$ & $\begin{array}{l}\text { School } \\
\text { principal }\end{array}$ & Yes & $\mathrm{E} 1 ; \mathrm{E} 2$ & Mainstream School \\
\hline SUP & 31 years old & Pedagogy & $\begin{array}{l}\text { Municipal } \\
\text { Supervisor }\end{array}$ & Yes & All & $\begin{array}{l}\text { Secretariat of } \\
\text { Education }\end{array}$ \\
\hline
\end{tabular}

Note. Participants were assigned initials to facilitate identification, being F family, P teacher, CP pedagogical coordinator, DC school principal, and SUP municipal supervisor of education. The letters $\mathrm{C}$ and $\mathrm{E}$ are added to the initials to indicate whether the professional worked in the mainstream (C) and/or special school (E), as well as the number of the participant in the research and the abbreviation SRM indicating to the teacher of a Multifunctional Resources Classroom. 


\section{Instruments}

Participants responded to a semi-structured interview, whose questions sought to assess attitudes, facts, and data regarding school transfers. A pilot script of the interview was elaborated, being then submitted to judges, all of them PhDs in the field of Special Education. After suggestions of changes, the script was resubmitted to the judges, obtaining final approval. The interview has a part dedicated to the participant's socio-demographic and professional data, and another part with seven discursive questions related to the school transfers of students with ID.

\section{Procedure}

Data collection. The interview was conducted with the research participants individually. Data collection was carried out in municipal schools selected for the study, during meetings and HTPC (Collective Pedagogical Working Time) schedules of these schools, at the CAEE (Specialized Education Center) of the city hall and in the special school of a city of the countryside of São Paulo.

Data analysis. Data analysis began by listening and transcribing interviews. To have an understanding of each participant's general context of speech, each interview was listened to individually. For Spink (2010), it is fundamental to understand that all discursive analysis involves other elements that go beyond the discourse itself. Questions asked during the interview refer to people's opinion about a particular event, in this case, the school inclusion of the investigated students and their school transfers. Data analysis sought to list categories after the interviews, using the discursive analysis technique: Maps of Association of Ideas of Spink (2010), currently called only Maps. The choice of themes, which in this work are called axes, implies the positioning of the researchers face the interview data. "Positioning implies navigating the multiple narratives we come into contact with and that are articulated in discursive practices" (Spink, 2010, p. 36).

\section{Ethical Considerations}

The research was submitted and approved by the ethics committee of the Education Department of the city where the study was conducted. The research project was submitted to the National Commission for Research Ethics (CONEP) and obtained approval under CAEE number 27367714.2.0000.5504. All requirements implied in CONEP Resolution No. 466, of December 12, 2012, were observed.

\section{Results and Discussion}

Results are composed of thematic categories identified in the participants' answers to the research questions, according to the data analysis method. In all, five thematic axes are presented, which are discussed from literature research.

\section{Teacher Training, Unpreparedness and Lack of Information}

Teacher training and lack of preparation were pointed out by some participants as important elements that end up interfering in the way the school transfer of a student with ID happens and in the student's school inclusion as a whole. For some, especially the family members, "making sure" inclusion "works" is the responsibility of the regular classroom teacher of the mainstream school. "The teacher is the main subject of inclusion, because they are the one who teaches" (F2); "Because they are there to teach good to the students" (F5). For this participant, many students who were transferred from the special to mainstream school were rejected by the educators due to the lack of preparation and training, because they did not know and did not take an interest in knowing the student with ID. To this mother, regarding the transfer of her daughter: "Many teachers did not know her (medical) reports, so they did not know what to do" (F5).

For the municipal supervisor of education, the lack of preparation is not only in the teachers but in the entire educational network, which is partly due to an initial training that is deficient regading the school inclusion of the SPED student, as pointed out by Capellini and Rodrigues (2009). For the participant, continuing education courses must show results, be promoters of effective changes in the praxis of teachers and school leaders, and not be just another diploma. For the supervisor, "I think the difficulty is the teaching itself, isn't it?!, and that includes teachers, networks, the municipality itself in the matter of continuing education, these are all fundamental in this process" (SUP).

Regarding teacher training, nine of the ten professionals participating in the research had a specialization course recognized by the MEC on Special Education. Interestingly, most of them pointed out the need for more continuing education courses. This data directs the discussion to an important aspect. For these professionals, the programs for the continuous training of teachers advocated by the National Policy on Special Education in the Perspective of Inclusive Education (Ministry of Education, 2008) have not been effective since they did not provoke changes in conceptions, practice and teaching with the SPED student.

As a suggestion, SUP proposes that continuing education courses should be offered not only by the network, but also by colleges as extension projects. SUP points out that, in the case of ID, one cannot blame the lack of resources as an impediment to schooling in the common classroom, as the participant understands that not so many physical materials are needed, as in the case of other deficiencies, and since the necessary resources can be made by the teacher himself. The greatest difficulty would then be how to make the student learn. This data was also found in the research by Leite and Martins (2010). This difficulty related to lack of preparation goes beyond educators. For the participants, it is part of a general context. 
As pointed out by the participants in the Leite and Martins (2010) research, courses are needed for the School Director to address certain types of disability, offering internships as a way to prepare the teacher. "I think it's the preparation of both the teacher and the system. ... I think it would lack of even experience, knowledge and also an internship with that type of disability" (DC). For the mother of a student with ID (F4), school professionals would benefit from a course on the student with ID. In the conception of the participant, the novelty might frighten, "shock" due to the lack of information and knowledge of the professional before the student. She states that mothers know about this fear of teachers with their children, which leads them to fearing leaving their children in the mainstream school. Fear of them being discriminated against, of not having their needs met.

As the research by Manzini and Glat (2014) points out, for these participants the teachers' lack of technical preparation and of specific training ends up significantly interfering in the transfer of students and in the process of school inclusion itself. In addition to the lack of training, many participants reported that mainstream school professionals feel unprepared, and even the possibility of teaching a SPED student would make them scared, afraid (Participants DC; CP; PC5; PSRM; DE). Fear here is related to "not knowing what to do," and believing that these students exhibit unpredictable behaviors and demeanors. "I think the lack of preparation of mainstream classroom professionals that is. . . they are always trained, they are, but it is still scary. So when you say 'I'm going to receive a child with intellectual disability', they do 'hum' [scare expression]. At first it freaks them out" (PSRM).

For the participants, special school professionals are accustomed to SPED students and, for this reason, they are not surprised or afraid nor do they reject the students. In this regard, they would be more prepared because of their professional experience with students with ID. These notes corroborate other researches, which point out the presence of students with ID in the regular classroom still is a reason for strangeness, regardless of the degree of qualification of the teacher, indicating the presence of a feeling of unpreparedness regarding the inclusion of students with ID (Braun \& Marin, 2012; Crochík, 2012).

The AEE teacher argues that because she is experiencing two realities, as an AEE teacher in an SRM and in the other period as a general education teacher, she notes that there is a commitment of the municipal government in the technical preparation of professionals. In her view, the difficulty comes from a resistance, on the part of the professionals of mainstream schools, in receiving the students with DI. For the participant, these professionals are evaluated by the students' learning, mainly by tests such as Prova Brasil and SARESP (School Performance Evaluation System of the State of São Paulo), and having a student with learning difficulties or ID represents a challenge to the levels of grades that students need to achieve in these tests. She also points out the resistance in searching for material, making changes and adaptations in class to suit all students.
I think the city hall is preparing the professionals a lot, but there are still those, not all, who have a resistance, who want a higher learning index. . . They are required to do this... then you still have a little bit of resistance on the issue of assessment and curriculum adaptation, which has to work differently indeed. One must have an adapted curriculum, one must have all the adaptation. I think that forecloses a little bit this issue of curricular adaptations, yet, but I think it is going to be all right. (PSRM)

Faced with the difficulties pointed out by the participants, there is a lack of knowledge about mechanisms that help the teacher and the regular school staff in the inclusion process, since several strategies have already been proven effective by a considerable amount of research in the area. For example, the collaborative teaching proposal (David \& Capellini, 2014; Mendes, Cia, \& Cabral, 2015) and the PEI (Individualized Education Plan) are tools that significantly aid the inclusion of students with ID.

Finally, it is important to highlight the demand of teachers for specific courses on each disability, in this case on intellectual disability. Perhaps underlying this demand is an understanding that intellectual disability is something concrete and not a construct, and that special education has recipes ready to teach from the common label of intellectual disability. However, students with ID vary considerably in the level of development and learning, fact which makes it seem useless to place them in the same category on the premise that there must be something common in the education of these students, due to a supposed intellectual deficit.

On the other hand, the specific formation in ID may be important to demystify this concept, to undo the stereotypes and prejudices attributed to this group of students, since no generalization can be made about how to teach them. Therefore, it is important for teachers to be able to examine and challenge their beliefs so that they can use new practices. It is worth noting that it does not seem sufficient to provide professional training for the use of techniques and resources in the case of school inclusion. As pointed out by Omote et al. (2005), it is necessary to construct a new vision of school, student, teaching and learning, one that corresponds to the paradigm of the real movement of social inclusion.

\section{Lack of support}

Participants listed different forms of support that, in their view, should be present in the transfer of any student, to make the process more natural for them and their new school: the support of a team of professionals, the municipal secretariat of education and of the school's own professionals. Support by a team of professionals, such as psychologists and speech therapists, becomes essential since, as they are present in the specialized institution, they should also be in mainstream schools. For the participants, the presence of these professionals would help in the transfer of the students and would enable their permanence in the general education. 
Thus, the school must be structured to receive students with inappropriate behavior, either by continuing education, classroom adaptation and support of a team of professionals. With or without ID, students with behavior problems exist and require the school's attention. As seen in national and international surveys, support services are rarely present in schools (Kelly, Devitt, O'Keeffe, \& Donovan, 2014; Oliveira et al., 2013). There is a lack of legislation to support the school and stipulate the types of support needed and how to enable the permanence of students with ID in the general education school.

For the PC4 teacher, the lack of support from other professionals of the school and the municipal secretariat of education were obstacles to the creation of conditions for teaching her student with ID. The teacher argued she used to adapt the material by making a handout to help her student, but the school did not allow printing due to containment of funds. Because of the student's behavior and the number of students in her classroom, which in her conception prevented a greater dedication and attention to this, the teacher says she sought the Municipal Department of Education to request the presence of a caregiver. According to the participant, the secretariat helped at first, but now it did not give her any more support. The teacher PC4 states that enrolling the student in ordinary school without providing the necessary support to them and to the teacher is not school inclusion. PC4 also stressed the importance of supporting the teacher during the transfer of students, so that they feel prepared and confident to deal with different demands in the classroom. This support, for the participant, must come from the school board and the municipal secretariat of education. In addition to the lack of support and adapted material, as already presented, there was also a lack of adequacy of evaluations. Noticing the impossibility of understanding the requirements of evaluations, parents report the children with ID and their colleagues developed a mechanism that, however inadequate it might have been (cheating on the test), was the only way to overcome the lack of accessibility.

They give her a test, she cannot read... how will she answer the test? And the teacher says he can not explain because he has too many students. Then the colleagues help. They do their test, throw them to the student E5 to copy them without the teacher seeing, and do the test for her. And there are teachers who have no patience, the director has no patience. When she has a homework she asks for help from her sister, but she does not understand. (F5)

According to participant F5, her daughter was unmotivated by her studies and did not wish to return to school next year. As in Isabel's case in the research of Campos and Glat (2016), the student's constant failings made it difficult for her to coexist with classmates due to distance of age and interests, which may be associated with the student's lack of motivation to finish her studies. Kelly et al. (2014) corroborate with the parents' report. For these Irish researchers, the lack of support services for students in transition from schools may be the main factor responsible for the failure of transferring students from the special school to the mainstream school. The lack of human, material, pedagogical and training resources to work with the student with ID is pointed out in another research as an obstacle to the effective inclusion of the student in a mainstream school (Oliveira et al., 2013).

\section{Lack of preparation for school transfer}

According to the participants' reports, in all cases of school transfer they participated, either directly or indirectly, there was no form of preparation, be it for the special school, mainstream school, family and for the student with ID. It is clear the school transfers the respondents participated in took place without prior planning, possibly due to the disagreement between the often opposing views of the family and school. Participant F4 reported that her daughter, when she moved from the special school to the mainstream school, came back home crying every day, which demonstrates the importance of preparation for the transition between schools. According to her report, for the participant F4 her daughter was not ready, stating the transfer must proceed a whole process of evaluation and preparation.

The importance of this evaluation, which must be global, is clear. It would assess the student's difficulties and needs and lay out a plan of action for the then new school. Taking back Veltrone and Mendes (2012), the assessment of a student with ID must aim not only at the diagnosis and classification, but also at the definition of the necessary supports for a truly effective school inclusion that brings benefits to the student.

In this context, it is clear that the lack of support, material and personal resources, as well as the lack of effectiveness of initial and/or continuing training, indicate the school transfer of students with ID needs attention at the national level. Without prior planning, the transfer is mostly based on arbitrary issues, argued for individual reasons, preventing the possibility of forecasting the necessary supports. Therefore, it is important to point out how essential prior planning is since, as already seen, school transfer can end up affecting in many ways, not always positive, the professionals, family and especially the students. To transfer a student without previous evaluation and planning is to bet on luck, on "it might work", a fact that is unacceptable in all areas, mainly legally and morally.

Another issue to consider in transferring students with ID is related to how these supports will be offered to/by the school, which also includes the type of support needed, the location and by whom. It is suggested that schools prepare for such decisions and provisions of support and resources, considering the policy of school inclusion in general and assessing the needs and resources that must be available on a case-by-case basis. For this to be effective in school practice, it is emphasized that such reflections should consider the real possibilities of Brazilian education today.

\section{Expectations regarding the student with ID}

Based on the analyzed cases, we could identify the expectations of schools and families regarding the inclusion and academic performance of students with ID, as well 
as some characteristics attributed by the participants to these students. For the participants, some characteristics are desirable and favor the inclusion of students in mainstream schools. The following behaviors and abilities were identified as desirable and facilitating: ease of socialization and interaction with colleagues, passivity, social skills in general (making friendships, respecting professionals) (Participants F1, F3, DE, DC, CP, PE1, PE2, PSRM, PC4). Becoming independent of special school care was also pointed out as a facilitator of inclusion in the mainstream school (Participants F1, F4, PC4, PE1, PE2, DE). Another aspect highlighted was the overcoming of their limits and the improvement in learning (Participants F1, F5, PE2, DC, DE, CP, PCE1).

In many cases reported, the learning difficulties are attenuated, in the discourse of the participants, due to the ease of socialization presented in the mainstream school, as affirmed by DC. Characteristics equally desirable to the student with ID listed by the school professionals are: evolution in academic performance that demonstrates that the student can benefit from teaching in general education, social skills that allow the student to be socially accepted by the group of classmates and educators, and the fact the student does not have a serious level of intellectual impairment.

However, it should be pointed out that professionals tend to attribute more positive characteristics to the inclusion process of students who do not display conflicts and aggression. These students are usually more accepted by peers (Cabral, 2011). However, in the case of students with ID that have inappropriate or aggressive behaviors, interaction and acceptance by peers and school professionals tend to be smaller (Cabral, 2011). In the case of other students, autonomy in personal care (food and locomotion), proactive behavior, ease of socialization and learning were mentioned as factors that favored schooling in a mainstream school.

Although the participants pointed out the presence of appropriate and desirable behaviors, some characteristics of the students were pointed out as obstacles to inclusion. These include behaviors seen as inadequate (aggressiveness, dependence), need for support for activities of daily living, and learning difficulties. For the participants, the presence of these characteristics is a fundamental factor so that the schooling in mainstream school is successful or unsuccessful.

For the participants in the case of F2's granddaughter, their behavior was so inadequate they justified any action taken in their schooling, such as the transfer to a special school after four months in the mainstream school, for the student's own good (participants DE, PE2, PC2, DC, $\mathrm{CP}$ ). The teacher's lack of patience with her justified, to her grandmother (F2), the school transfer. "Her behavior was bad because if it was good... [she would have stayed in the mainstream school]. She had a teacher for 30 days. This one had a little patience, but in the end, there was not even patience left" (F2).

It seems reasonable, but it is not. Referral to special school seems to have been more of a relief to teachers and principals than a potential benefit to the student herself. For general education teachers, the special school would be a place to address "difficult or unsolved cases". As the problem is attributed to the student, it is difficult for the actors in this case to visualize another aspect: the context in which complaints of behavior and school difficulties are produced and the role of educators and school management in dealing with it. In the study by Góes (2012), the parents stated they initially sought the mainstream school but, due to the difficulties found, they eventually chose to enroll their children in special education schools. In the case of student E2, the family had no choice. After the rejection by mainstream schools, the only option of schooling was the specialized institution.

However, for the Supervisor (SUP), any student behavioral problems are dismissed as an impediment to inclusion, and she pointed out the greatest difficulty is for the teacher to know how to "treat" the student. Considering the context of speech, treating can be considered as meeting the needs in all aspects, one of them being to teach.

In the inclusion of these students, the greater difficulty of teachers is how to treat them, as they are more common. It's easy to take in a child with intellectual disability, because it does not give you problems. They're in the room, quiet most of the time. Or they are a student with that most difficult behavior, but he is easy to deal with.... What we see happening is that they are isolated and go through the entire process, from the first to the fifth year, without any effective learning. (SUP)

A different conception is adopted by the principal DC, who starts from the premise that students with ID are difficult, demand a lot of attention because of their difficulties, requiring from the teacher "patience" (sic): "So, although it is patience that you need the most, it really is patience, dear, it is patience, because they are so much [work]. . . they require a lot. . take a lot from the teacher" (DC1).

The important caveat here is that any problems of behavior, adjustment and integration of students are not due to ID, and in many cases may be the result of a lack of a transition plan between the two forms of schooling, as well as the late entry into the curriculum of the special school and an over-reliance on support services (Kelly et al., 2014). Often, the failure of this transfer is attributed to the characteristics of students with disabilities, not consider ing the essential role of a network of support services for students in transition, since the absence of such services may be one of the factors responsible for the failure of the transfer of students from the special to the mainstream school.

\section{Learning and School Performance Expectations}

Some participants pointed out that characteristics related to student learning are related to the process of transfer and adaptation of these students in schools. For teacher PSRM, teachers require more results related to the learning of students with disabilities in comparison with other students without disabilities. For the principal DC, the inclusion of students 
with ID is more difficult when compared to students with other disabilities or conditions. In the case of some students, the difficulty to learn was pointed out as the main element for non-stay in the mainstream school and consequent transfer to the special school. Examples of answers in this sense are: "He did not stay there because he cannot learn, he has a lot of difficulty" (PE); "He has a lot of learning difficulties, which made it difficult for him to stay in the mainstream school. For the rest, he is a great student [referring to student behavior]" (DE); "He is evolving but he is not ready yet to study in a mainstream school. He still has not demonstrated that he knows $100 \%$, the moment he knows $100 \%$ he would be able to go back to the other school" (F3); "She has a lot of difficulty. She has a very compromising issue in her development" (PE2).

It is not clear what the real difficulty of the students is. Using the terms employed by the participants, it is something in the development, in the mind, but what that would be no one could explain. Being the problem focused on the student figure, the difficulty is considered to be theirs, and then it would be plausible to know it so to solve it. Regarding learning, the point in which the student is and where they should go is also unclear. It is only known that he has a delay because he does not accompany the class.

Teacher PSRM points to the need for individualized teaching and evaluation process, which considers the students' gains, even if they are small and alert to the risks of comparing the performance of students with ID and of those without disabilities. "You have to evaluate the students in relation to themselves. Because the gains are small and slow. The teacher adds: 'That's why here [SRM] I try to compare the student's current performance with himself in the past. I try to pass this vision to the teachers of the general education, but there they do not do so" (PSRM).

This indicates there still is a great difficulty in assessing the student with ID and their needs, both educational and of support. Once again the evaluation proves to be fundamental since it enables the intervention with the students, demonstrates what to do and makes it possible to do it. As long as there is this difficulty in assessing needs, students and teachers will remain in this "unknown territory," preventing a real evolution in learning.

The negative perception because due to learning difficulties ends up falling as the student's responsibility, because they are the one who does not learn, who is slow, who "has difficulties", who "cannot". As demonstrated by Pletsch and Glat (2012), this is partly due to the overvaluation of cognitive abilities over others, which leads educators to perceive students with ID as ineligible for formal learning. Such perspectives point to how urgent is the transformation of one's own conception of learning, both of parents and of teachers and managers, as something that goes beyond the grades of tests or the ability to read and write. It is necessary to understand learning as a multi-dermal process (Lima \& Mendes, 2011), so that one can identify gains and evolutions of the student with ID.
In this context, another discussion related to the overvaluation of academic learning for ID diagnosis may also emerge. Although adaptive behavior gains an emphasis on the 2002 definition of the American Association on Intellectual and Developmental Disabilities [AAIDD], 2008. on the characteristics and diagnostic criteria of intellectual disability, enabling a new way of seeing the subject with ID, in practice this change did not occur. The participants' discourse allows us to infer the learning of academic content remains the chief car for the characterization of students with ID.

One can verify in the reports the parents' belief the special school can, in some cases, offer better conditions for the process of schooling of their children with ID, as seen in Góes (2012). This fact is exemplified in the case of the family of student E3, who seeks the specialized institution because they believed the child would be supported and have better teaching and learning conditions. Fact that was fulfilled after the transfer of E3 to the special school, even if late. The proponents of schooling students with ID in general education argue the typical classroom promotes a better psychological development, especially from the social point of view, as it promotes friendship and social acceptance, improvement in self-concept, higher rate of appropriate behaviors and less oppositional behavior (Vianello \& Lanfranchi, 2011). Others point out there is greater stimulation of the student's abilities in the mainstream classroom (Buckley, Bird, Sacks, \& Archer, 2006). However, the question as to what is the best form of schooling for the student with ID still remains unanswered.

The greatest desire of the family members interviewed is that the students are literate, regardless of age and method. Being literate represents for some that the student has achieved, has exceeded its limits, so that it will really be included in society and will be able to enjoy all the benefits that being literate can bring; access to a better job (F3) or a better future quality of life (F2; F4). For many families (F1; F2; F4, and F5) the mainstream school is the only one that can provide this. For this reason, they committed themselves to the school transfer. The special school is seen by parents as a place of care, of affection, but not of academic learning. Thus, transference is motivated by this something else that, in the conception of parents, the common school can provide: literacy. Concerning the choice of schooling, parents tend to prefer schooling in mainstream school the lower the degree of commitment of the child is. For students with more severe disabilities, parents point out that both forms of schooling may benefit the students. However, parents of students with multiple and severe disabilities tend to prefer specialized institutions, believing there their children will have more support from teachers (Gasteiger-Klicpera, Klicpera, Gebhardt, \& Schwab, 2013).

For the Multifunctional Resources Classroom teacher PSRM, the student's performance is directly proportional to the difficulties associated with the ID level. Students with ID at a mild level are able to be literate; however, those at the advanced levels (moderate and severe, for example) have 
greater impediments and often cannot learn academic skills due to cognitive limitations.

Regarding the expectation of school professionals related to student performance, data shows that teachers expect from ID students the same academic performance as non-disabled students, which directly affects teaching practice. Literature review has shown several studies affirming the lack of teacher's knowledge on the development of subjects with ID and on alternative pedagogical practices are factors hindering the schooling of such students in general education classrooms (Campos \& Glat, 2016; Santos \& Martins, 2015). Most often, teaching practices have not been altered in any way to meet the educational needs of these students (Duarte, 2012; Pletsch \& Glat, 2012). This can be seen in the five cases studied in this research, more explicitly in the cases of students E3 and E5, in which no teaching adequacy was carried out by the school. However, this inertia is not exclusive to the mainstream school. Many studies show that, in specialized institutions, the teaching strategy can be marked by "routinization of activities and nonexploitation of students' manifestation" (Maturana \& Mendes, 2018). Returning to Omote (2003), in order to assert itself, school inclusion requires a revision of traditional pedagogical practices. Another important factor that impairs student learning and performance is the lack of articulation of the ESA curriculum with that of regular classrooms.

It is known that conceptions and representations are predictors of behavior, that is, through the conceptions of the subject it is possible to predict the behaviors it will have in certain situations. Thus, data of this present study allow to affirm the postures presented are probably due to the teachers' and family members' understanding of difficulty as inherent to the student, that their losses are fixed and immutable, and that differentiated pedagogical measures and practices have little or no effect. Such a conception should be debated, as well as conceptions about the learning capacities of students with ID. The study contributes by pointing out that expectations about student performance and learning, as well as their conceptions about what is intellectual disability, guide their perceptions of what would be the ideal form of schooling for the student with ID, both for school professionals as for the family. We alert to the fact that processes of identification, evaluation, and referral of students with disabilities in school transfer processes are closely related to the concept of deficiency held by professional and school. Both in the evaluation as in the referrals of the student with ID for services, a clear definition of criteria is required. In this context, the participants' attention to the importance of the support team to help the school professionals throughout this process it is understandable, as well as to the previous preparation of teachers, students and family. Only with the involvement of all professional staff can one avoid that subjectivities and arbitrariness interfere with this process.

\section{References}

American Association on Intellectual and Developmental Disabilities. (2008). Definition of intellectual disability. Retrieved from http://aaidd.org/intellectual-disability/ definition\#

Braun, P., \& Marin, M. (2012). Práticas docentes em tempos de inclusão: Uma experiência na escola básica [Teaching practices in times of inclusion: An experience in basic school]. e-Mosaicos, 1(2), 2-12. doi:10.12957/e-mosaicos.2012.5152

Buckley, S., Bird, G., Sacks, B., \& Archer, T. (2006). A comparison of mainstream and special education for teenagers with Down syndrome: Implications for parents and teachers. Down Syndrome Research and Practice, 9(3), 54-67. doi:10.3104/reports.295

Cabral, F. A. (2011). Inclusão escolar no ensino fundamental: Estudo das relações sociais entre os alunos com e sem deficiência intelectual [School inclusion in elementary school: Study of social relations between students with and without intellectual disabilities] (Master's thesis). Retrieved from https://sapientia.pucsp.br/handle/handle/10293

Campos, K. P. B, \& Glat, R. (2016). Procedimentos favoráveis ao desenvolvimento de uma criança com Síndrome de Down numa classe comum [Procedures favorable to the development of a child with Down Syndromeinacommonclass]. EducaçãoEspecial,29(54), 27-40. doi:10.5902/1984686X10399

Capellini, V. L. M. F., \& Rodrigues, O. M. P. R. (2009). Concepções de professores acerca dos fatores que dificultam o processo da educação inclusiva [Teachers conceptions about the factors that hinder the process of inclusive education]. Educação, 32(3), 355-364. Retrieved from http://revistaseletronicas.pucrs.br/fass/ ojs/index.php/faced/article/view/5782

Carneiro, M. S. C. (2008). Do ensino especial ao ensino regular: Tentativas de integração escolar de alunos considerados portadores de necessidades educativas especiais [From special education to regular education: Attempts at school integration of students considered as having special educational needs]. In A. V. Zanella, M. J. T. Siqueira, L. A. Lhullier, \& S. I. Molon (Orgs.), Psicologia e práticas sociais [Psychology and social practices] (pp. 163-172). Rio de Janeiro, RJ: Centro Edelstein de Pesquisas Sociais.

Crochík, J. L. (2012). Fatores psicológicos e sociais associados ao bullying [Social and psychological factors associated with bullying]. Revista Psicologia Política, 12(24), 211-229. Retrieved from http://pepsic. bvsalud.org/scielo.php?script=sci_arttext\&pid=S1519549X2012000200003 
David, L., \& Capellini, V. L. M. F. (2014). O ensino colaborativo como facilitador da inclusão da criança com deficiência intelectual na educação infantil [Collaborative teaching as a facilitator of the inclusion of children with intellectual disabilities in early childhood education]. Nuances, 25(2), 189-209. doi:10.14572/nuances.v25i2.2714

Duarte, M. (2012). Alunos com síndrome de Down na escola: Histórias de vida de pessoas que concluíram o Ensino Fundamental [Students with Down Syndrome in school: Life stories of people who have completed Elementary School]. Plures Humanidades, 13(1), 13-30. Retrieved from http://seer.mouralacerda.edu.br/index.php/plures/ article/view/20

Gasteiger-Klicpera, B., Klicpera, C., Gebhardt, M., \& Schwab, S. (2013). Attitudes and experiences of parents regarding inclusive and special school education for children with learning and intellectual disabilities. International Journal of Inclusive Education, 17(7), 663-681. doi:10.1080/13603116.2012.706321

Góes, R. S. (2012). A escola de educação especial: Uma escolha para crianças autistas e com deficiência intelectual associada de 0 a 5 anos [The special education school: A choice for autistic children with associated intellectual disabilities from 0 to 5 years old] (Master's thesis). Retrieved from http://www.teses.usp.br/teses/disponiveis/47/47131/ tde-08112012-151609/pt-br.php

Kelly, A., Devitt, C., O’Keeffe, D., \& Donovan, A. M. (2014). Challenges in implementing inclusive education in Ireland: Principal's views of the reasons students aged $12+$ are seeking enrollment to special schools. Journal of Policy and Practice in Intellectual Disabilities, 11(1), 68-81. doi:10.1111/jppi.12073

Leite, L. P., \& Martins, S. E. S. O. (2010). Avaliação do instrumento de adaptações curriculares na organização de ações educacionais inclusivas [Evaluation of the instrument of curricular adaptations in the organization of inclusive educational actions]. Revista e-Curriculum, 5(2), 1-22. Retrieved from http://revistas.pucsp.br/index. php/curriculum/article/view/3358/2233

Lima, S. R., \& Mendes, E. G. (2011). Escolarização da pessoa com deficiência intelectual: Terminalidade específica e expectativas familiares [Schooling of people with intellectual disabilities: Specific terminology and family expectations]. Revista Brasileira de Educação Especial, 17(2), 195-208. doi:10.1590/S1413-65382011000200003

Manzini, E. J., \& Glat, R. (2014). Influência das representações sociais do pesquisador na análise de dados de entrevistas: um estudo no campo da educação especial [Influence of researcher's social representations in analysis of interviews: a study in the field of special education]. Archivos Analíticos de Politicas Educativas, 22 (79). doi: 10.14507/epaa.v22n79.2014
Maturana, A. P. P. M., \& Mendes, E. G. (2018). A contribuição das pesquisas nacionais sobre a escolarização de estudantes com deficiência intelectual [The contribution of national research on schooling of students with intellectual disabilities]. Veredas FAVIP, 1, 35-58. Retrieved from http://veredas.favip.edu.br/ojs/index. $\mathrm{php} /$ veredas $1 /$ article/view/599

Mendes, E. G., Cia, F., \& Cabral, L. S. A. (2015). Inclusão escolar e os desafios para a formação de professores em educação especial [School inclusion and challenges for teacher education in special education]. São Carlos, SP: Marquezine e Manzine.

Ministério da Educação. (2008). Política Nacional de Educação Especial na perspectiva da educação inclusiva [Special Needs Education National Policy on an inclusive education perspective]. Brasília, DF: O Autor. Retrieved from http://portal.mec.gov.br/arquivos/pdf/ politicaeducespecial.pdf

Oliveira, A. A. S., Valentim, F. O. D., \& Silva, L. H. (2013). Inclusão escolar: Um novo modelo de escola [School inclusion: Anew school model]. In Avaliação pedagógica: Foco na deficiência intelectual na perspectiva inclusiva [Pedagogical evaluation: Focus on intellectual disability in an inclusive perspective] (pp. 15-21). São Paulo, SP: Cultura Acadêmica.

Omote, S. (2003). A formação do professor em Educação Especial na perspectiva da inclusão [The training of the teacher in Special Education in the perspective of inclusion]. In R. L. L. Barbosa (Org.), Formação de educadores: Desafios e perspectivas [Educators' training: Challenges and perspectives] (pp. 153-169). São Paulo, SP: Editora Unesp.

Omote, S., Oliveira, A. A. S., Baleotti, L. R., \& Martins, S. E. S. O. (2005). The social attitudes adjustment towards inclusion. Paidéia (Ribeirão Preto), 15(32), 387-396. doi:10.1590/S0103-863X2005000300008

Pletsch, M. D., \& Glat, R. (2012). A escolarização de alunos com deficiência intelectual: Uma análise da aplicação do Plano de Desenvolvimento Educacional [The schooling of students with intellectual disabilities: An analysis of the application of the Educational Development Plan]. Linhas Críticas, 18(35), 193-208. Retrieved from https://www.redalyc.org/html/1935/193523804012/

Santos, T. C. C., \& Martins, L. A. R. (2015). Práticas de professores frente ao aluno com deficiência intelectual em classe regular [Teacher practices facing the student with intellectual disability in regular class]. Revista Brasileira de Educação Especial, 21(3), 395-408. doi:10.1590/S1413-65382115000300006

Spink, M. J. (2010). Linguagem e produção de sentidos no cotidiano [Language and production of senses in daily life]. Rio de Janeiro, RJ: Centro Edelstein de Pesquisas Sociais. 
Veltrone, A. A., \& Mendes, E. G. (2012). Impacto da mudança de nomenclatura de deficiência mental para deficiência intelectual [Impact of changing nomenclature from mental disability to intellectual disability]. Educação em Perspectiva, 3(2), 359-373. doi:10.22294/eduper/ppge/ufv.v3i2.235

Vianello, R. L., \& Lanfranchi, S. (2011). Positive effects of the placement of students with intellectual developmental disabilities in typical class. Life Span and Disability, 14(1), 75-84. Retrieved from http://www.lifespan.it/client/abstract/ENG219_5.pdf

Yin, R. K. (2014). Case study research: Design and methods (5th ed.). Thousand Oaks, CA: Sage.

Ana Paula Pacheco Moraes Maturana is a Post. Doc. Researcher of the Faculdade de Ciências, in Bauru, of the São Paulo State University

Enicéia Gonçalves Mendes is a Professor of the Psychology Department of the Universidade Federal de São Carlos, in São Carlos.

Vera Lúcia Messias Fialho Capellini is a Professor of the Faculdade de Ciências, in Bauru, of the São Paulo State University.

Authors' Contribution:

All authors made substantial contributions to the conception and design of this study, data analysis and interpretation, and to the manuscript revision and approval of the final version. All the authors assume public responsibility for the content of the manuscript.

Received: Jun. 01, 2017

1st Revision: Aug. 17, 2017

Approved: May. 22, 2018

How to cite this article:

Maturana, A. P. P. M., Mendes, E. G., \& Capellini, V. L. M. F. (2019). Schooling of students with intellectual disability: Family and school perspectives. Paidéia (Ribeirão Preto), 29, e2925.doi:http://dx.doi.org/10.1590/1982-4327e2925 